\title{
Deformation in axial compression of aluminum tubular structures with ribs
}

\author{
Keisuke YOKOYA ${ }^{1}$, Makoto MIYAZAKI $^{2 *}$, Yusuke TOJO ${ }^{3}$ and Minoru YAMASHITA ${ }^{4}$
}

Dynamic compression behavior of various kinds of polygonal tubular structures with ribs are investigated. Square hollow structures and that with rib reinforcement of aluminum extrusions are in dynamic axial compression, using a drop hammer. Numerical simulation was also conducted for the wider variety of cross-sectional shapes and reinforcements. The effect of the axial length, cross-sectional shape and reinforcing rib arrangement on the deformation behavior were investigated. Comparable compressive force was obtained when the cross-sectional area of the structure is similar, even if the number of edges in cross-section increases from four (square) to eight. Rib reinforcement is very effective for the improvement of the crush or energy absorbing performance. Deformation behavior was successfully predicted by the numerical simulation. Numerical simulation of the compression of the various polygonal tubular structures with radial ribs was also carried out. The number of radial ribs in cross-section of the polygonal hollow structure has a positive relationship to the deformation constraint at corners and the torsional rigidity, consequently, the crush resistance increased.

(Received December 22, 2018 Accepted May 30, 2019)

Keywords: tubular structure; dynamic buckling; torsional rigidity

\section{1. 緒言}

金属管はフレームや構造物へ広く使用されている部材であ り, 古くから変形挙動に関する研究が行われている。円管に ついては鋼管に関する報告が多く，静的，準静的，動的圧縮 試験によって，変形挙動が検討されている ${ }^{1) \sim 3)}$ 。角管につ いても鋼管の報告が多く, 円管と同じように実験的検討や 理論的検討が行われ, 動的座屈現象の解明が進められてい る $^{4) \sim 8)}$ 。

アルミニウム合金は，比重が鉄鋼の1/3であるが，その反 面縦弾性係数も同様である。そのため, 単に材料を鉄鋼か ら置き換えただけでは，製品の剛性は確保できない。さら に，剛性の向上のために肉厚を厚くすると，角管全体が大き く座屈する軸圧縮変形となり，衝突時のエネルギーを有効に 吸収できないという問題が報告されている。しかし，アルミ ニウム合金は押出成形性に優れており，断面設計の自由度が

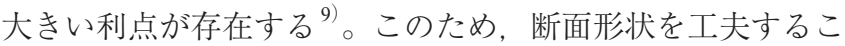
とで，肉厚を厚くすることなく部材の剛性を確保できる。ま た，押出成形による製造コストの削減も期待できる。このよ うに，アルミニウム合金は軽量化と高強度を両立できる素材
であり，自動車などの構造強度部材としての用途が注目され

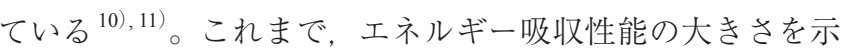

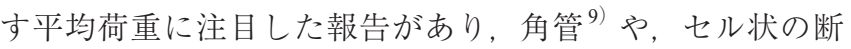
面を持つ筒状体 ${ }^{12)}$ について検討されている。また，テーパ 形状を有する角管についても検討されている ${ }^{13)}$ 。平均荷重 はエネルギー吸収性能との関係が指摘されており，筒状体の 最終的な変位量との積によって吸収エネルギーを算出でき る ${ }^{12)}$ 。そのため, 平均荷重は単位変位量あたりのエネルギー 吸収量を示しており, 筒状体のエネルギー吸収性能の評価に 有効である。しかし，剛性や変形荷重の向上に有効とされる 補強リブを内部に設けた筒状体に関しては，その設計指針と なる変形特性などのデータが不足している現状がある。これ までに，著者らの一部は，角管の軸圧縮変形挙動に関して実 験と有限要素法による数值計算を行い，角部のねじり剛性が 変形形状の決定と圧縮荷重に寄与することを示した ${ }^{14)}$ 。正 多角形断面の筒状体についても，軸圧縮時のエネルギー吸収 能に及ぼす影響を検討した ${ }^{15)}$ 。その結果，平行な対面を有 しない奇数角については, 座屈しわの周期性が崩れるため, 塑性変形によるエネルギー吸収部材として適さないことを示 した。また，実際に筒状体が圧縮変形するとき，軸長が短く

${ }^{1}$ 長野工業高等専門学校専攻科 生産環境システム専攻（テ381-8550 長野県長野市大字德間 716）〔現在：東京工業大学 工学院 機械 系機械コース 修士課程2年（广 152-8550 東京都目黒区大岡山2-12-1)] Advanced Course of Production and Environment System, National Institute of Technology, Nagano College (716 Tokuma, Nagano-shi, Nagano 381-8550) 〔2nd Year Master's Student, Mechanical Engineering Course, Department of Mechanical Engineering, School of Engineering, Tokyo Institute of Technology (2-12-1 Ookayama, Meguro-ku, Tokyo, 152-8552)]

${ }^{2}$ 長野工業高等専門学校 機械工学科（長野市） Department of Mechanical Engineering, National Institute of Technology, Nagano College (Naganoshi, Nagano)

${ }^{3}$ 株式会社デンソーエアクール（安量野市）ＤENSO Aircool Corporation (Azumino-shi, Nagano)

4 岐皁大学工学部機械工学科 (岐皁市) Department of Mechanical Engineering, Gifu university (Gifu-shi, Gifu)

* 責任著者E-mail: miyazaki@nagano-nct.ac.jp 
なるにつれ，端面間距離の影響が変形挙動に現れる場合があ る。これは, 塑性変形に先立って生じる弾性変形によるもの と言える。弾性変形は筒状体全体に生じ，その形状は周期的 かつ波状という特徵を有する ${ }^{16)}$ 。このため，軸長に応じて 弾性変形の形状は変化し, 続く塑性変形の形状にも影響を及 ぼす。その後，ひずみが集中する箇所より塑性変形を生じ, 最終的に筒状体は周期的な蛇腹状の座屈変形を示す。このよ うに，実用的な設計デー夕としては，筒状体の長さの影響も 検討すべき事項である。

これまでに，筆者らの一部は，既報において，四角形筒 状体を対象に，初期不整が変形形状に及ぼす影響を検討し た ${ }^{17)}$ 。また，リブを有さない多角形筒状体のひずみ分布を 検討し，軸長が長くなるとひずみが小さくなり，発生位置が 移動することを確認した ${ }^{18)}$,19）。また，補強りブを有する筒 状体において，どの軸長でも局部的な変形形状が得られるこ とを確認し，衝撃吸収部材への可能性を確認した ${ }^{20), 21) 。 ~}$

しかし，広範囲の軸長に関する報告は少なく，特に座屈の 発生箇所など変形過程に及ぼす影響については，ほとんど検 討されていない。

本研究では，軽量高強度な筒状体断面の設計指針の基礎 デー夕を得るため, 動的軸圧縮変形を受ける多角形筒状体に ついて検討することとした。まず，変形シミュレーションの 信頼性を確認するため, 角管の動的軸圧縮試験を行い, 結果 を比較した。その後, 多角管の角数と内部に設ける補強リブ が変形挙動に及ぼす影響について，変形シミュレーションを 用いて検討した。

\section{2. 実 験}

\section{1 実験方法}

本実験で用いた落すい式衝撃試験機を Fig. 1 に示す。おも りの衝突速度は落下する高さにより評価でき, 最大 $10 \mathrm{~m} / \mathrm{s}$ ま で変化させることができる。本実験における落すいの質量は $15 \mathrm{~kg}$ であり, 衝突速度は最大の $10 \mathrm{~m} / \mathrm{s}$ とした。供試材の両端 はFig. 2 に示すような鋼製の幅 $2 \mathrm{~mm}$, 深さ $5 \mathrm{~mm}$ の溝付きプ レートにて変位を拘束した。溝付きプレートの下に, 鋼製土 台を介して設置した自作のロードセルにて衝撃荷重を測定し た。過去に著者らの一部は鋼製ハット型強度部材の衝撃試験

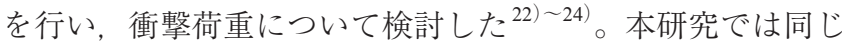
衝撃試験装置を用いて実験を行った。前回と同様にロードセ ルは衝撃に強いSNCM447鋼製ブロックに半導体ひずみゲー ジ（共和電業(株), KSN-2-120-E4-11）を貼付したものを用い た。ロードセルの固有振動数は，サンプリング周波数と比較 し，十分に大きいことから，測定にあたってフィル夕処理は 行わなかった ${ }^{24)}$ 。高速度カメラを用いて，供試材の変形過 程についても記録した。撮影方向はFig. 1 中に矢印に示す通 りである。撮影した動画は $640 \times 512$ pixel，フレームレートは $1000 \mathrm{fps}$ である。供試材はA6063-T5アルミニウム合金製四角 管（板幅 $w=40 \mathrm{~mm}$ ，軸長 $l=100 \sim 300 \mathrm{~mm}$ ）である。Table 1 に 供試材の化学成分を示す。ここでは，断面にリブを持たない 角管を Type A と呼び, リブを有するものを Type B と呼ぶこ ととする。肉厚 $d$ は Type Aが $1.1 \mathrm{~mm}$, Type Bが $1.5 \mathrm{~mm}$ である。 供試材の例を Fig. 2 に示す。上側が本実験で用いた供試材で あり，下側が鋼製プレートである。

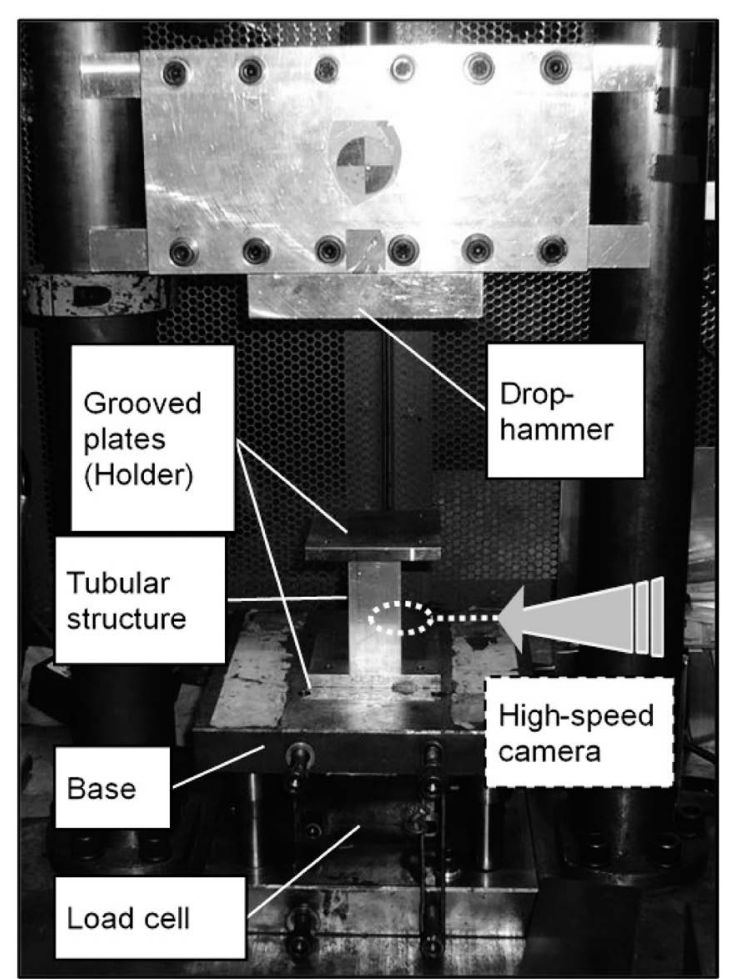

Fig. 1 General view of dynamic compression test using drop-hammer.
( a )
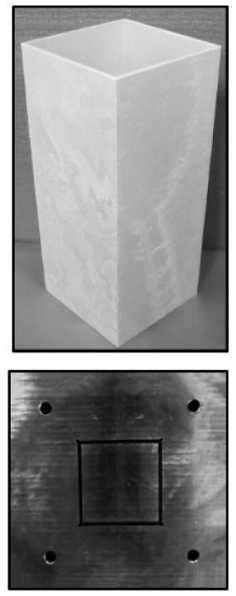

(b)
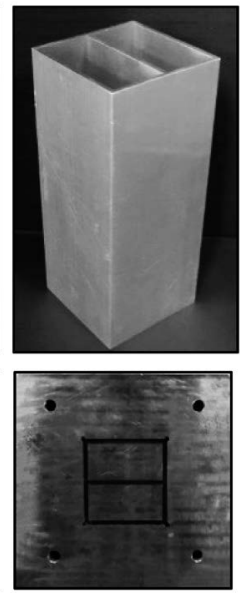

Fig. 2 Grooved plates and square tubular structures. (a) Type A and (b) Type B (with internal rib).

\section{2 実験結果と検討}

高速度カメラで撮影された角管の変形過程を Fig. 3 に示 す。ここでは, 落すいが衝突端部に接触してからの時間 $t$ に おける変形過程を示している。なお, Fig. 3(b) 中に示す点 線はType Bの補強リブの位置を示している。Fig. 4 に供試 材の変形の模式図を示す。Fig. 3(a) より, Type Aは衝突後 $t=1 \mathrm{~ms}$ において, Fig. 4(a) に示すような, 壁面が完全に折 りたたまれていない波状の「うねり」変形が生じた。うねり は座屈が進行するごとに増加していき, それらが圧縮され密 になり，そのまま壁面が折りたたまれる蛇腹状の変形へと推 移する。ここでも, 衝突端部側ではそのまま座屈が折り重な るようにして逐次座屈が起こり, 最終的に蛇腹状の変形形状 となった。また, Fig. 4(b) に示すように，隣接する面にて 凹凸状に座屈した。リブを持たない四角管の場合では, 直辺 
部から座屈が始まり，続いて角部が座屈することが知られて いる ${ }^{25)}$ 。本研究においても, Fig. 3(a) に示すように, Type $\mathrm{A}$ の各面は直辺部から角部の順で変形が進行したものと考え られる。Type Bについては，下端部から座屈が生じた。軸長 $150 \mathrm{~mm}$ を下回る場合では, 衝突端部から座屈することが多 いものの，このオーダーの衝撃速度では必ずしも衝突端部に て座屈を生じるわけではないことが知られている ${ }^{26)}$ 。Type B のリブを有する面では, リブの座屈形状の影響を受けて変形 が進行している。また, 衝突後 $t=1 \mathrm{~ms}$ の変形形状を見ると, リブと隣接している手前側の面では, 座屈変形におけるうね りは内向きに生じている。これは, Type Aに対して Type B の肉厚が厚いため, 角部のねじり剛性が増加したためと考え られる ${ }^{14)}$ 。最終的に, リブに隣接している壁面は, リブの 座屈形状に沿うように変形しており, Type Aの変形形状と比 較して，Fig. 4(c) に示すようなリブを境にずれるような局 部座屈を生じた。

各軸長における変形形状を Fig. 5 に示す。今回検討した範 囲では，すべて衝突端部または下端部よりに，局部的な座屈 が生じた。

\section{3. 変形解析}

\section{1 解析方法}

解析には沉用非線形構造解析プログラムMarc2016を使用 した。解析モデルの例を Fig. 6 に示す。検討した各種断面形 状を Fig. 7 に示す。断面形状は，筒状体の外周の長さをほぼ 一定にするため, 半径 $r=20 \sqrt{2} \mathrm{~mm}$ の円を描き，それに内接 する正多角形断面である。角管は 4 節点 4 辺形厚肉シェル要

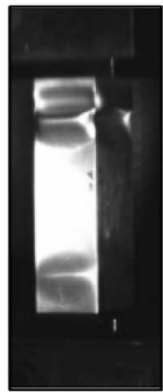

$t=1 \mathrm{~ms}$

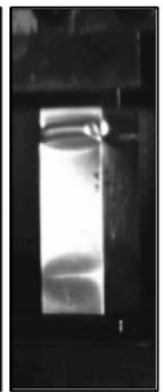

$t=3 \mathrm{~ms}$

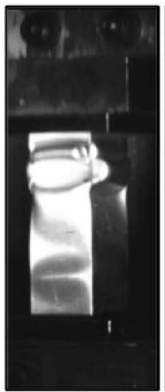

$t=5 \mathrm{~ms}$

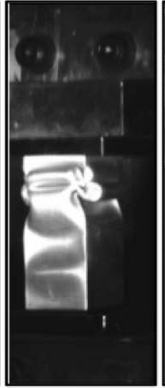

$t=9 \mathrm{~ms}$

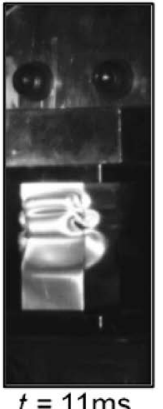

(b)

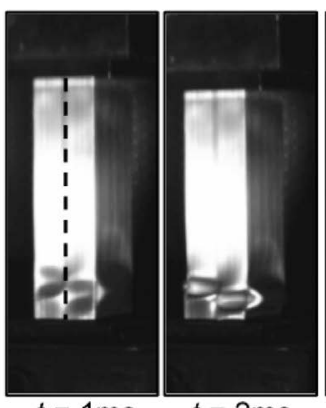

$t=1 \mathrm{~ms}$

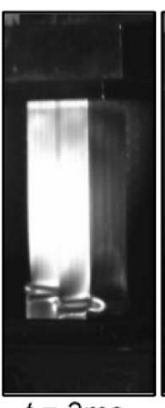

$t=3 \mathrm{~ms}$

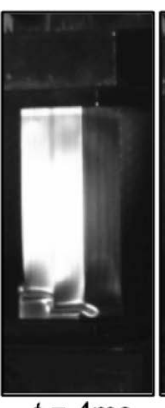

$t=4 \mathrm{~ms}$

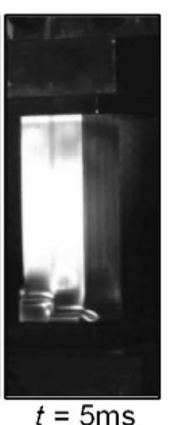

Fig. 3 Dynamic deformation behavior of aluminum tubes with $150 \mathrm{~mm}$ length. (a) Type A and (b) Type B.
素で構成した。また, 補強リブはType Bを除いて対角線上 に設けた。Type Bについては，ある一面から対面に向けてリ ブを設けた。肉厚はすべて $d=1.1 \mathrm{~mm} と し$, 軸長は $l=100$ $500 \mathrm{~mm}$ について検討した。各種断面形状における要素数を Table 2 に示す。要素サイズは2.0×2.0 mmである。静的引張 試験より求めた材料特性值を Table 3 に示す。エネルギー吸 収性の比較のため, Type Aの材料特性值についても Table 3 に示す Type B〜Iの值を用いた。角管端部の節点については 衝撃端の軸方向の並進運動を除き拘束した。落すいは 8 接点 3 次元ソリッド要素で構成した。角管と落すいとの間に摩擦 はないと仮定した。アルミニウム合金は鉄鋼と比べ，ひずみ 速度依存性が小さいとされている ${ }^{27)}$ 。本研究におけるひず

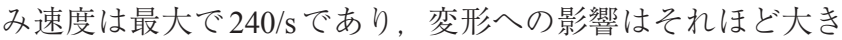
くないと考えた。そのため, 材料構成方程式にはひずみ速度 依存性のない式(1) を採用した。

$$
\sigma=F \varepsilon^{n}
$$

動解析の時間積分法としては, 陰解法のシングルステップ フーボルト法を用いた ${ }^{28)}$ 。ステップ幅としての時間増分は

(a)

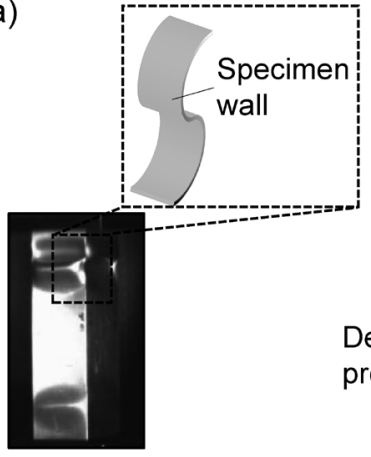

Wave-like manner

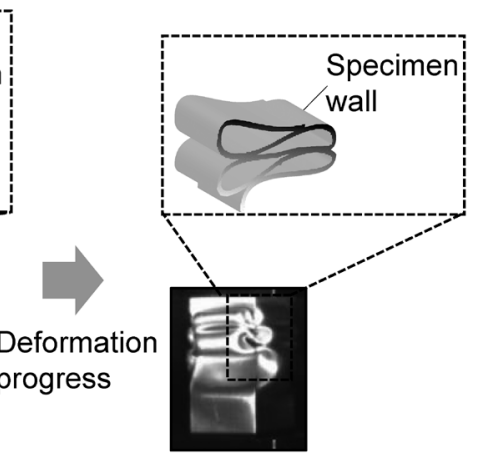

Bellows-like manner (b)

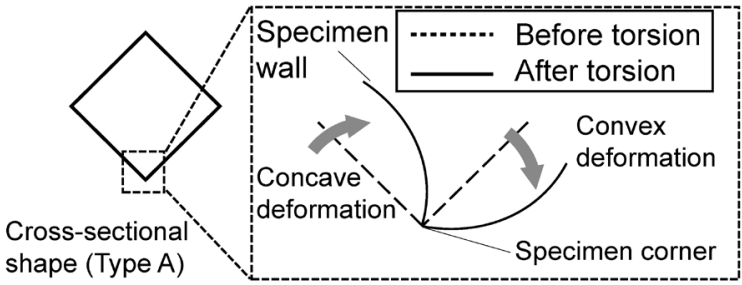

(c)

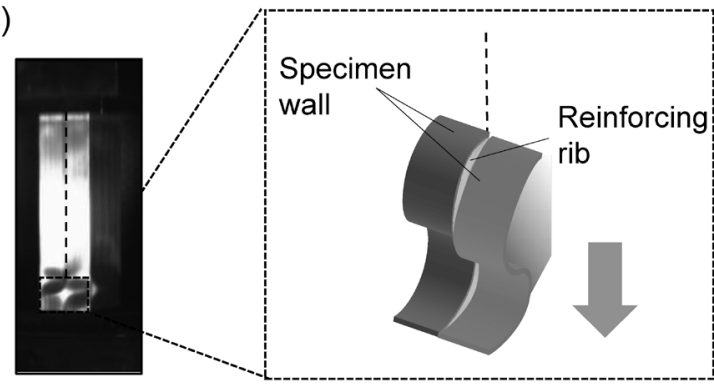

Fig. 4 Deformation shape of specimen wall. (a) wave-like and bellows-like manner of buckling wall, (b) concaveconvex deformation model by torsion of adjacent walls, (c) deviation of the face contacting rib.

Table 1 Chemical composition of A6063-T5 aluminum tubes specimen (\%).

\begin{tabular}{c|c|c|c|c|c|c|c|c}
\hline \hline $\mathrm{Si}$ & $\mathrm{Fe}$ & $\mathrm{Cu}$ & $\mathrm{Mn}$ & $\mathrm{Mg}$ & $\mathrm{Cr}$ & $\mathrm{Zn}$ & $\mathrm{Ti}$ & $\mathrm{Al}$ \\
\hline $0.20-0.6$ & -0.35 & -0.10 & -0.10 & $0.45-0.9$ & -0.10 & -0.10 & -0.10 & $\mathrm{Bal}$. \\
\hline
\end{tabular}


(a)

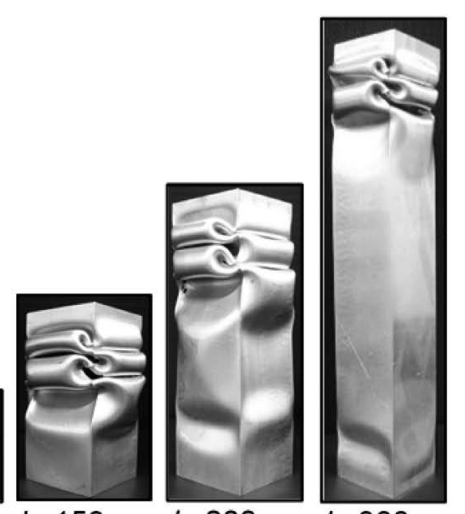

$I=100 \mathrm{~mm} I=150 \mathrm{~mm} I=200 \mathrm{~mm} I=300 \mathrm{~mm}$

(b)

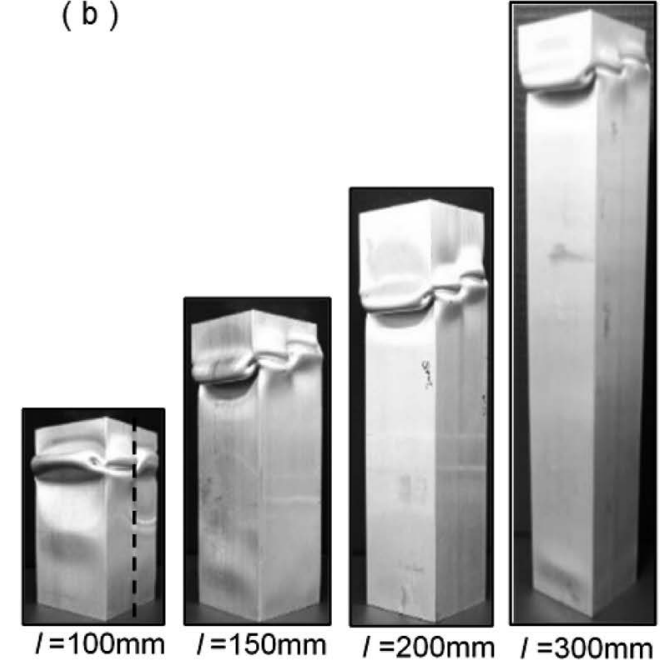

Fig. 5 Dynamically compressed tubular structures with various axial lengths. (a) Type A and (b) Type B ( $l$ : initial tubular length).

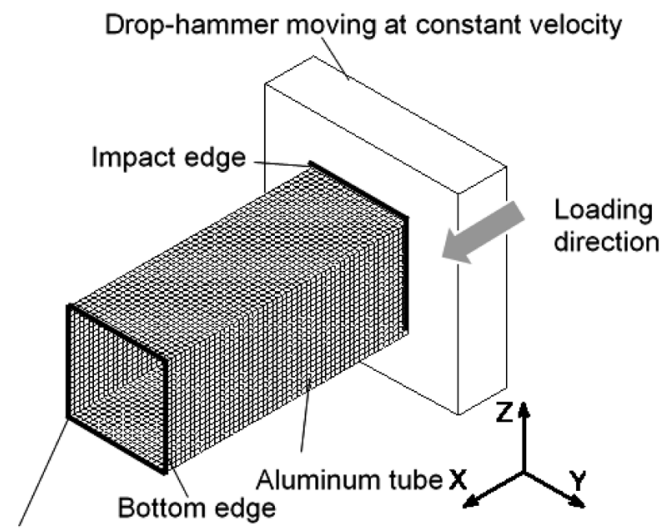

Nodes at bottom edge constrained in displacement and rotation

Fig. 6 An example of numerical model (Type-A, $l=100 \mathrm{~mm})$.
$0.5 \sim 1.5 \mu \mathrm{s}$ である。

\section{2 適切な初期不整の導入と実験結果との比較}

実験との比較を目的に, 衝撃試験と同様の形状を持つ角管 について解析を行った。肉厚は Type A で $1.1 \mathrm{~mm}$, Type Bでは $1.5 \mathrm{~mm}$ である。ここでは実験と同様の座屈形状を得るため, Type A では各面, Type Bでは補強リブの初期座屈箇所に Fig. $\mathbf{8}$ に示すような初期不整を導入した。初期不整の大きさ $d_{\mathrm{i}}$ は, 最大荷重に影響しない $0.1 \mathrm{~mm}$ 以下とした ${ }^{17)}$ 。Type A では衝 突端部からの距離 $l_{\mathrm{i}}$ で生じた初期座屈箇所において, 周方向 の凹凸状の変形の形状に合わせて導入した。また, Type B では衝突端部からの距離 $l_{\mathrm{i} 1}, l_{\mathrm{i} 2}$ に, リブの長手方向のうねり 変形の形状に合わせて導入した。軸長ごとの初期不整の導入 箇所と大きさを Table 4 に示す。変形形状を Fig. 9, 変形過程 における荷重履歴の例をFig. 10に示す。これらより，どの 場合においても, 変形形状はシミュレーションと実験にてお おむね一致していた。また, 荷重履歴についても, どの軸長 においても実験とシミュレーション結果が一致していた。ま た，筒状体の軸圧縮解析では，内部の空気によるエアークッ ションの影響が生じる場合がある。内部の空気が漏れないと 仮定し, 軸長が半分になった場合, その効果は $0.2 \mathrm{MPa}$ 程度 であり，荷重に与える影響は約 $0.3 \mathrm{kN}$ 程度である。よって， 本研究ではその影響は大きくないと思われる。以上より，本 シミュレーションは実験をよく再現できていると考えられる。

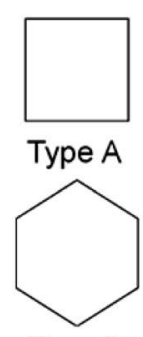

Type D

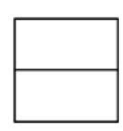

Type B

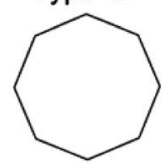

Type E

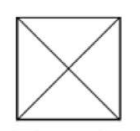

Type C

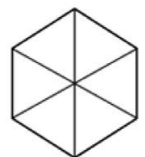

Type F
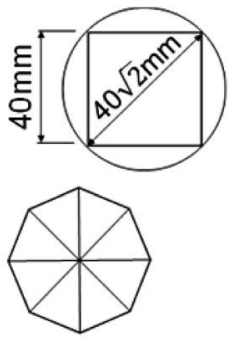

Type G
Fig. 7 Variations in cross-sectional shapes.

Table 2 Number of elements in various cross-sectional shapes.

\begin{tabular}{c|c}
\hline \hline Cross-sectional shape & Number of elements \\
\hline Type A & $4000-20000$ \\
Type B & $5000-20000$ \\
Type C & $6800-34000$ \\
Type D & $4200-20748$ \\
Type E & $4488-22352$ \\
Type F & $8232-41496$ \\
Type G & $10000-50000$ \\
\hline
\end{tabular}

Table 3 Material properties of A6063-T5 aluminum tubes.

\begin{tabular}{c|c|c|c|c|c}
\hline \hline Cross-sectional shape & $\begin{array}{c}\text { Young's } \\
\text { modulus, } \\
E / \mathrm{GPa}\end{array}$ & $\begin{array}{c}\text { Poisson's } \\
\text { ratio, } v\end{array}$ & $\begin{array}{c}\text { Density, } \\
P / \mathrm{kg} \mathrm{m}^{-3}\end{array}$ & $\begin{array}{c}\text { Work-hardening modulus, } \\
F / \mathrm{MPa}\end{array}$ & $\begin{array}{c}\text { Work-hardening } \\
\text { exponent, } n\end{array}$ \\
\hline $\begin{array}{l}\text { Type-A } \\
\text { Type-B-I }\end{array}$ & 69 & 0.33 & $2.7 \times 10^{3}$ & 350 & 0.160 \\
\end{tabular}




\section{3 解析結果と検討}

先に示す Fig. 7 の断面形状にて解析を行い, 荷重履歴につ いて検討した。平均荷重にて衝撃吸収部材としてのエネル ギー吸収性を評価でき，最大荷重の大きさにて衝突時の乗員 への衝撃の大きさを評価できる。また, 繰返し座屈に伴い, 周期的な応力変動が起こることが知られている ${ }^{24,26)}$ 。変形

(a)

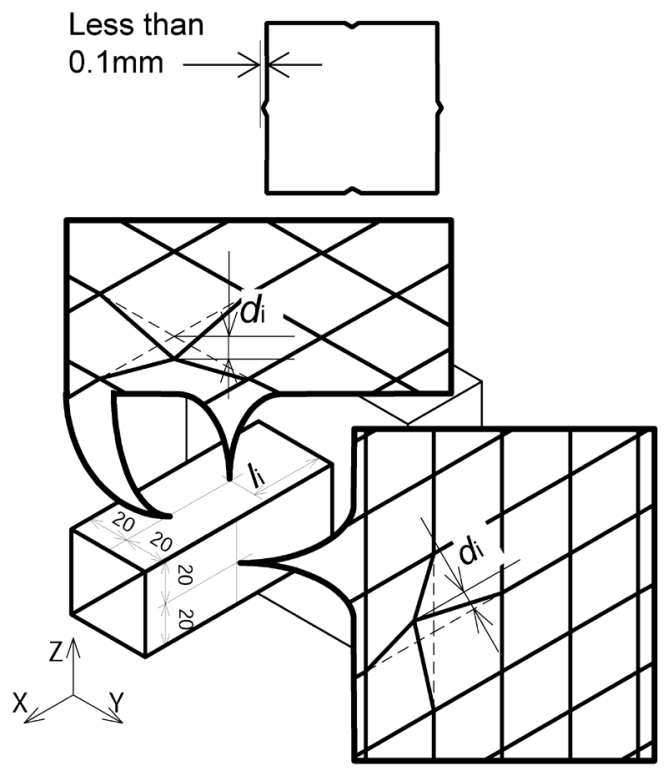

シミュレーションによって得られた最終変形形状を Fig. 11, 荷重履歴を Fig. 12 に示す。

Type Aの変形形状より, 軸長が短くなるほど, うねり变形 が進行する傾向が確認され，Fig. 12 (a) に示す荷重の変動周 期に差を生じている。しかし，平均的な荷重はほとんど同じ で，エネルギー吸収性能に対して影響は小であることがわか

(b)

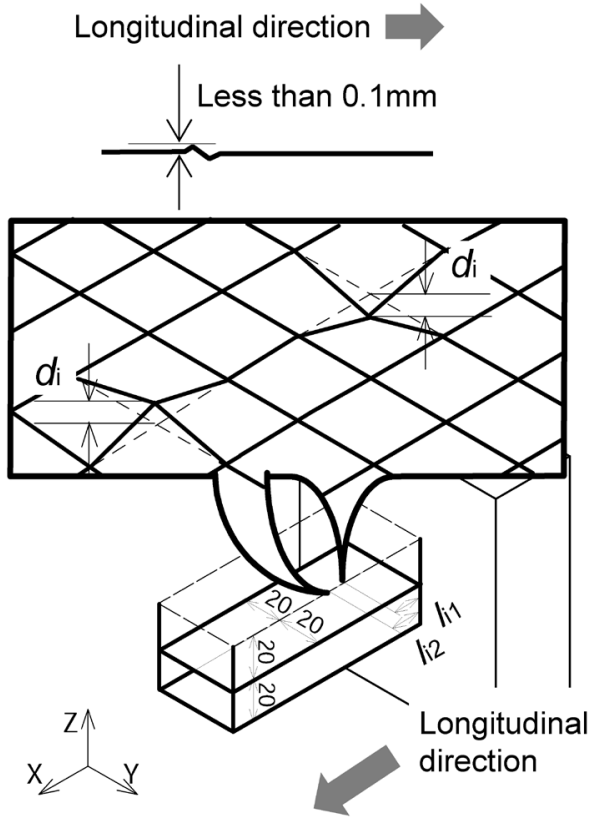

Fig. 8 The initial geometrical imperfection introduced at the portion of initial buckling. (a) Type A and (b) Type B.

Table 4 Introduced portions and sizes of geometrical initial imperfection.

\begin{tabular}{|c|c|c|c|c|c|c|c|}
\hline & Tubular length, $l / \mathrm{mm}$ & 100 & 150 & 200 & 300 & 400 & 500 \\
\hline \multirow{2}{*}{ Type A } & $\begin{array}{l}\text { Position of initial imperfection } \\
\text { from impact edge, } l_{\mathrm{i}} / \mathrm{mm}\end{array}$ & - & 22 & 24 & 26 & 24 & 22 \\
\hline & Size of initial imperfection, $d_{\mathrm{i}} / \mathrm{mm}$ & - & 0.1 & 0.05 & 0.1 & 0.05 & 0.1 \\
\hline \multirow[t]{2}{*}{ Type B } & $\begin{array}{l}\text { Position of initial imperfection } \\
\text { from impact edge, } l_{\mathrm{i} 1}, l_{\mathrm{i} 2} / \mathrm{mm}\end{array}$ & $2.4,3.8$ & $3.2,4.2$ & $3.2,5.6$ & $3.2,4.4$ & - & - \\
\hline & Size of initial imperfection, $d_{\mathrm{i}} / \mathrm{mm}$ & 0.01 & 0.05 & 0.05 & 0.01 & - & - \\
\hline
\end{tabular}

(a)

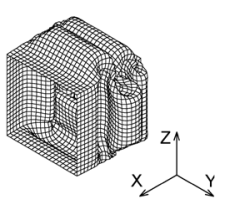

$I=100 \mathrm{~mm}$

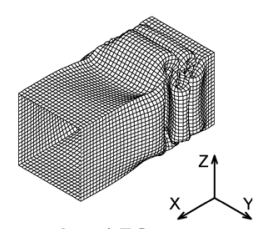

$I=150 \mathrm{~mm}$

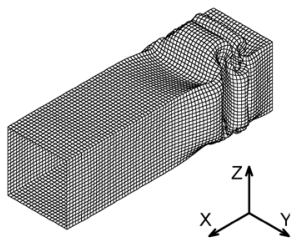

$I=200 \mathrm{~mm}$

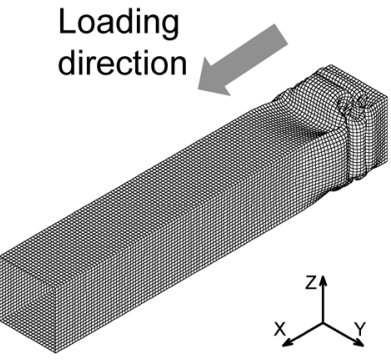

$I=300 \mathrm{~mm}$

(b)

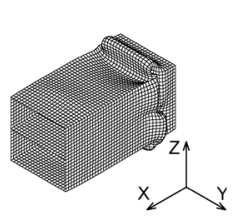

$I=100 \mathrm{~mm}$

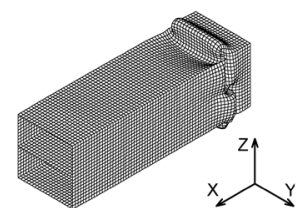

$I=150 \mathrm{~mm}$

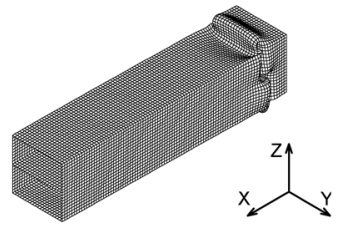

$I=200 \mathrm{~mm}$

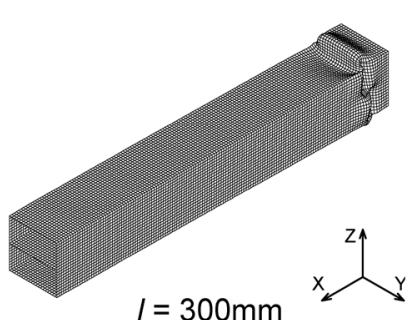

$I=300 \mathrm{~mm}$

Fig. 9 Predicted deformation shapes of tubular structures with various axial lengths. (a) Type A and (b) Type B. 
(a)

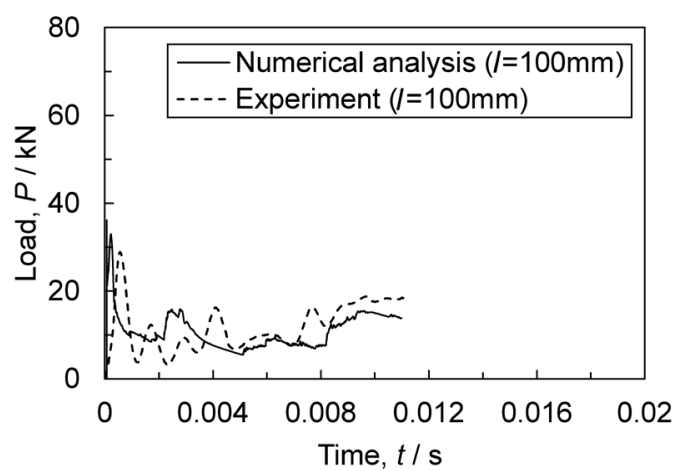

(b)

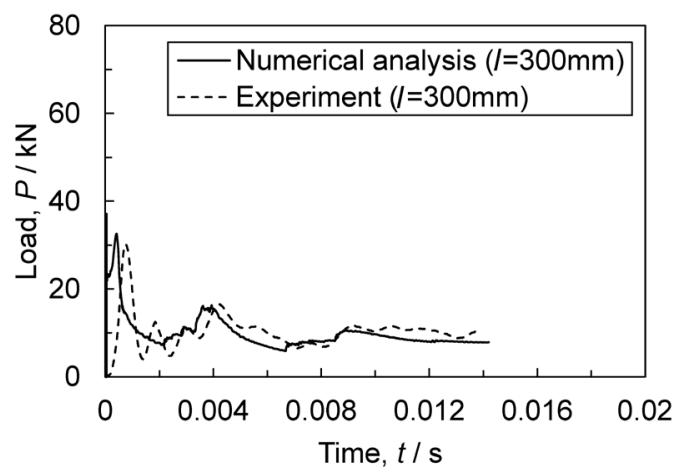

(c)

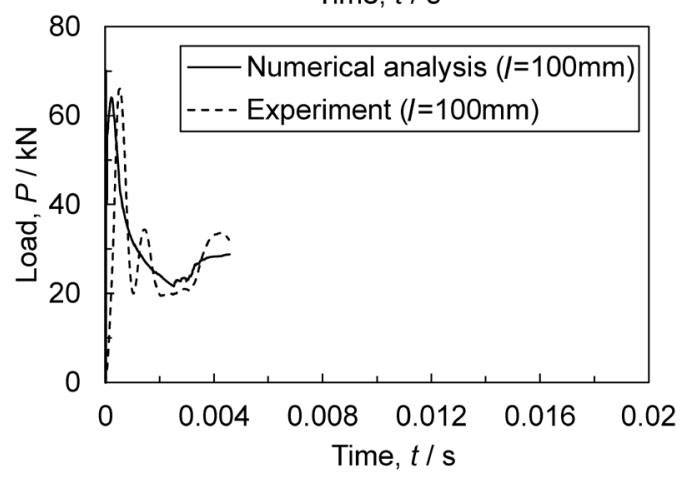

(d)

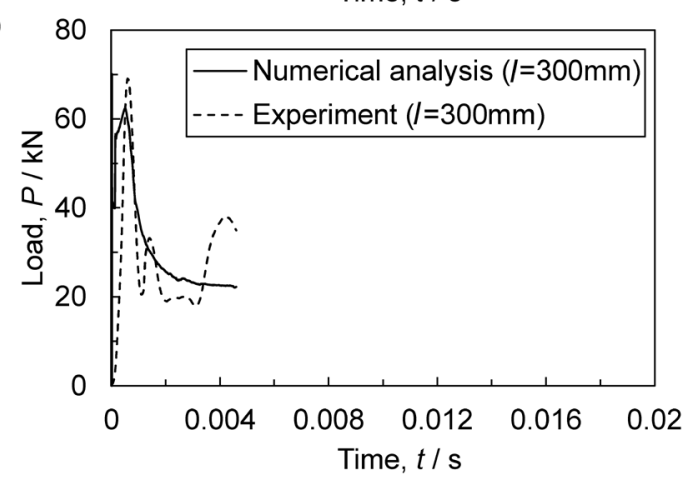

Fig. 10 Compressive load-time histories in numerical simulation and experiment. (a) Type-A $(l=100 \mathrm{~mm})$, (b) Type-A $(l=300 \mathrm{~mm})$, (c) Type-B $(l=100 \mathrm{~mm})$ and $(\mathrm{d})$ Type-B $(l=300 \mathrm{~mm})$.

る。また, 最大荷重 $P_{\max }$ の大きさも, 軸長の変化に影響を受 けていない。この傾向は Type $\mathrm{A} \sim \mathrm{G}$ のすべての断面形状で確 認された。各軸長に扮ける平均荷重 $P_{\text {ave }}$ を Fig. 13 に示す。断 面にリブのない管（Type A, D, E）では，Type Aにおいて平 均荷重 $P_{\text {ave }}$ が他の断面形状と比較して小さくなった。また, リブを有する管では平均荷重が大きくなった。本軸長の範囲 では, 軸長が変化しても, 平均荷重 $P_{\text {ave }}$ はType A〜Eではほ とんど変化せず, Type F, Gでは差異が生じていることが確 認された。これは, 後者では, 座屈で生じたうねり変形が,

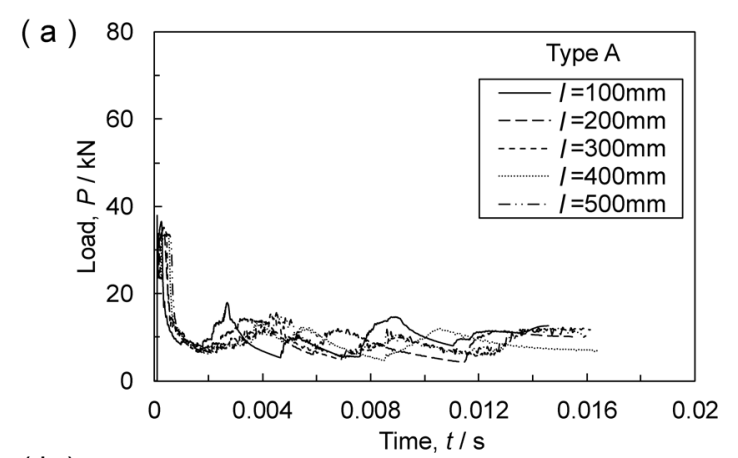

(b)

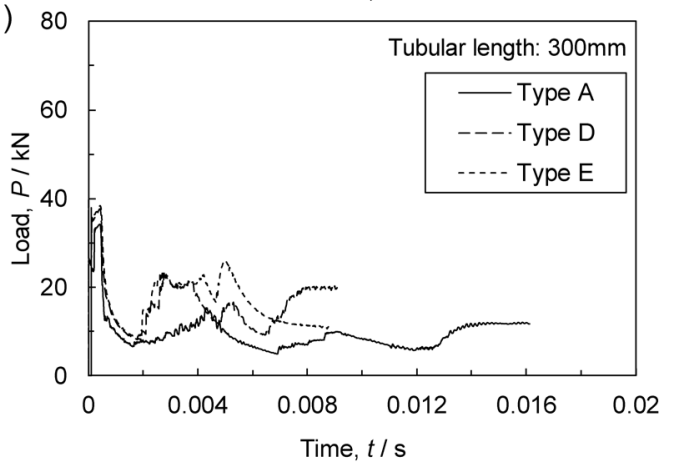

(c)
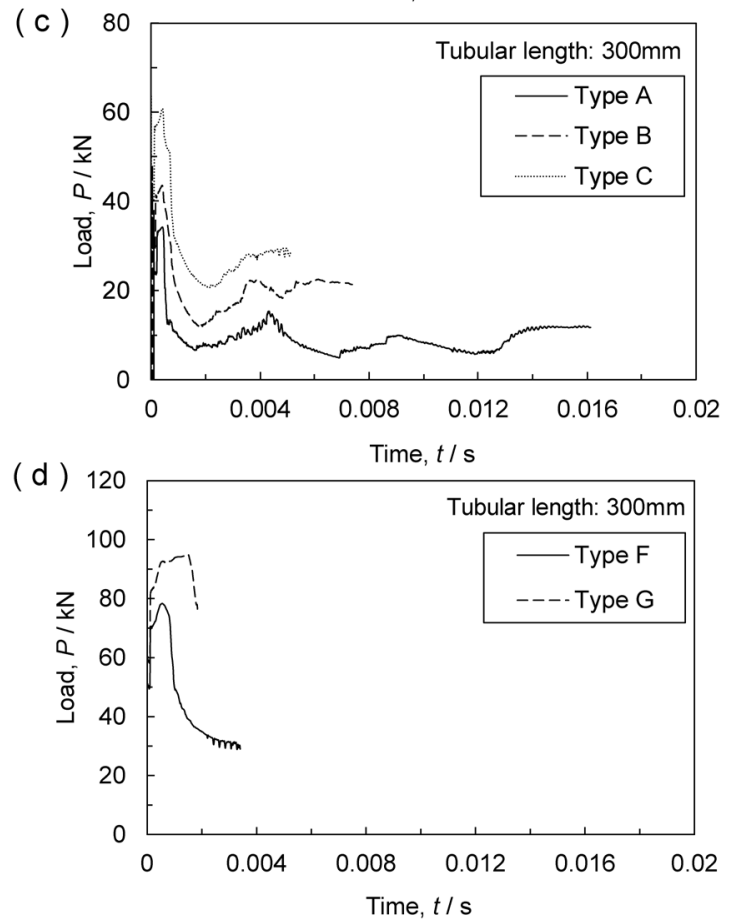

Fig. 12 Compressive load-time histories for various tubular length and cross-sectional shapes (a) Type A with various axial length, (b) Type A, D, E (no internal rib) with $300 \mathrm{~mm}$ length, (c) Type A, B, C with $300 \mathrm{~mm}$ length and (d) Type $\mathrm{F}$, $\mathrm{G}$ with $300 \mathrm{~mm}$ length.

密になって次のうねり変形を生じる前に, 変形が終了したた めである。

Fig. 12(b) より, Type Aにおいて $P_{\max }$ が他の断面形状と 比較してわずかに小さいことが確認された。Type D と Type Eを比較すると， $P_{\max } に ほ と ん と ゙$ 差がなかった。これは後述 のように，周長にほとんど差異がなかったためだと考えら れる。Fig. 12(c)，(d) より，リブの枚数が増加するにつれ て $P_{\max }$ が大きくなることが確認された。これは, 補強りブ によって角部のねじり剛性が向上したためだと考えられる。 Type G, Hでは, 前述のようにうねり変形が一つしか生じて 
(a)

( b ) (c)
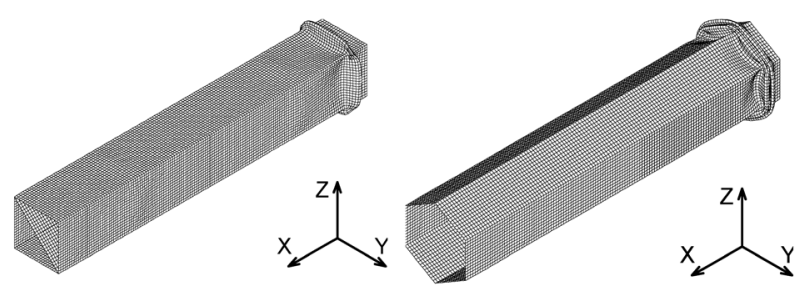

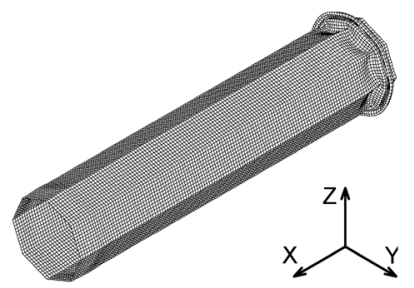

(d)

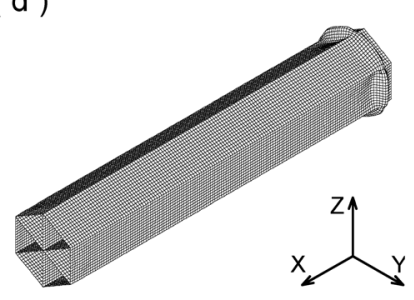

(e )

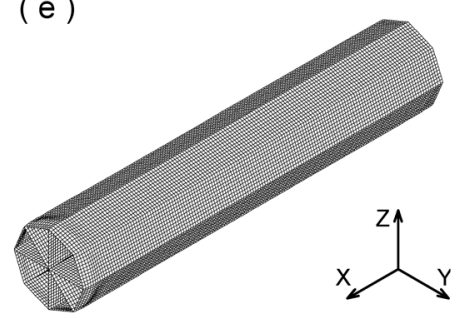

Fig. 11 Final deformation of analytical models (l=300 mm). (a) Type C, (b) Type D, (c) Type E, (d) Type F and (e) Type G.

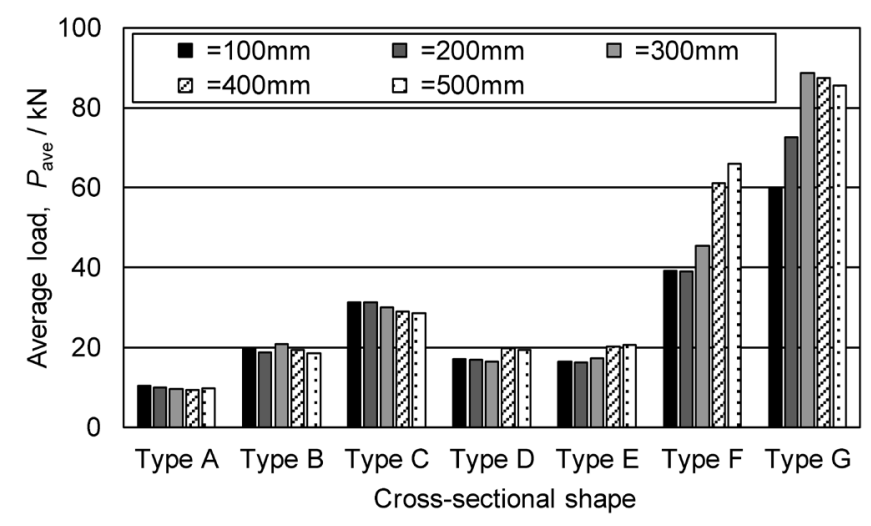

Fig. 13 Average load of tubular structures with various lengths.

Table 5 Torsional stiffness and maximum force of each cross-sectional shape.

\begin{tabular}{c|r|c}
\hline \hline Cross-sectional shape & $I_{\mathrm{B}} / \mathrm{mm}^{4}$ & $P_{\max } / \mathrm{kN}$ \\
\hline Type A & 6400 & 34.2 \\
Type D & 101823 & 37.7 \\
Type E & 118257 & 38.4 \\
Type F & 126490 & 37.2 \\
\hline
\end{tabular}

いないため, Fig. 12（d）に示すように荷重のピークは一つし か生じなかった。

以上より，断面の多角化と補強リブは平均荷重を向上させ るため, エネルギー吸収量の向上に有効である。しかし, 補 強リブは最大荷重も著しく向上させる。最適な補強リブの形 状については, 最大荷重がかかる時間を含めて, さらなる検 討が必要である。

ここで, 本研究の範囲では, 断面全体で軸回りのモーメン トが生じ，断面で角部を初めとしてねじれるような変形が生 じている。そのため, 多角管が動的軸圧縮される過程におい ては, 断面のねじり剛性が, 座屈変形に対する拘束の強さと みなすことができ, 最大荷重の向上に寄与していると考え た。最大荷重の向上の要因にはリブの張力による影響も考え られるが, 本研究では簡易的に断面のねじり剛性に着目し,
変形に対する拘束の強さを検討した。ここでは単純ねじりを 想定し, Saint-Venantのねじり理論に従うものとした。薄肉 閉断面のねじり剛性の算出にはBredtの式(2) を用いた ${ }^{29)}$ 。

$$
I_{\mathrm{B}}=\frac{4 A^{2}}{\frac{s}{d}}
$$

ここで， $I_{\mathrm{B}}$ は Bredtのねじり定数，Aは管の外周と内周の 中心線から内側の面積, $d$ は肉厚, $s$ は管の環断面の中心線 の長さである。 $I_{\mathrm{B}}$ と荷重履歴より得られた $P_{\max }(l=300 \mathrm{~mm})$ をTable 5に示す。これより, Type-Aは他の断面形状と比較 して $I_{\mathrm{B}}$ が小さく, 最大荷重も $10 \%$ 程度小さくなっているこ とが確認された。これは断面のねじり剛性が小さく, 弾性変 形に続いて生じる塑性変形が生じやすくなったためと考えら れる。Type D, Type E, Type Fについては $I_{\mathrm{B}}$ に大きな差異はな く, $P_{\max }$ もほとんど変化しなかった。これは断面形状が一定 の半径の円に内接するような多角形であり， $A$ と $s$ が大きく 変化しなかったためと考えられる。このように, 断面にリブ を持たない多角管では, 断面全体のねじり剛性が最大荷重に 影響を及ほしていると考えられる。

また, Saint-Venantのねじり理論に従うと, 断面のリブに 応力が生じないことが知られており ${ }^{29)}$, ねじり定数を算出 することは困難となる。そこで, 四角管の場合 ${ }^{14)}$ と同様に, 断面における角部のねじり変形が座屈形状に影響するものと 考え, 角部の断面二次極モーメント $I_{\mathrm{c}}$ からねじり剛性を評価 することとした。本研究の範囲では, まず辺部で座屈し, 最 後に角部が座屈する変形が生じたことから, 角部による拘束 が大きいと言える。そのため, 角部の剛性は辺部と比較して 影響が大きく, 実際の $I_{\mathrm{B}}$ との効果は近いと考えられる。実 際に角部と隣接する要素のみを $2 \mathrm{~mm}$ に厚肉化した場合には, 最大荷重で $9 \%$, 平均荷重で30\%増加することが確認された。 肉厚が一様でないため一概に比較することはできないが, 角 部の剛性の増加によって生じる荷重が増加したものと考えら れる。対角上にリブを有する断面において, 角部はFig. 14 に示すような五角形とし， I $\mathrm{c}$ を算出した。これは角部1個あ たりのねじり剛性であり, 角部の幾何学的形状の差異による ねじり剛性への影響を示している。なお Type Bにおける角 


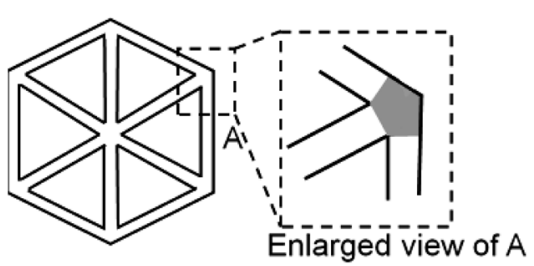

Fig. 14 Increase in torsional stiffness at corner portion of polygonal tube by additional ribs.

Table 6 Torsional stiffness of corner portion and maximum load of each cross-sectional shape.

\begin{tabular}{c|c|c}
\hline \hline Cross-sectional shape & $I_{\mathrm{c}} / \mathrm{mm}^{4}$ & $P_{\max } / \mathrm{kN}$ \\
\hline Type B & 0.17 & 43.6 \\
Type C & 0.30 & 60.9 \\
Type F & 0.35 & 78.3 \\
Type G & 0.38 & 95.0 \\
\hline
\end{tabular}

( a )
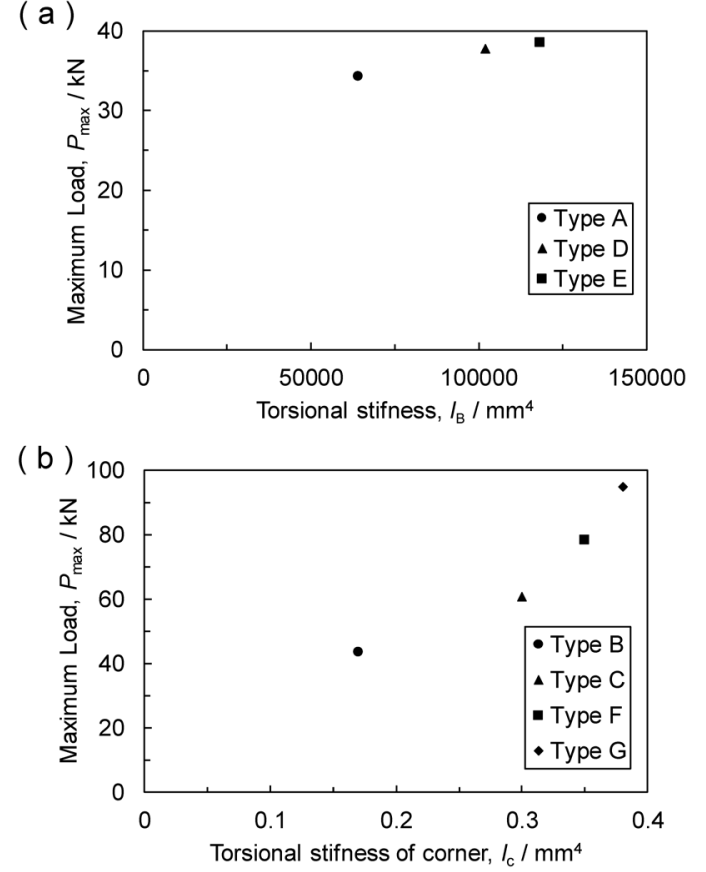

Fig. 15 Relationship between maximum load and torsional stiffness. (a) Torsional stiffness, (b) Torsional stiffness of corner.

部は正方形である。得られた $I_{\mathrm{c}}$ と $P_{\max }(l=300 \mathrm{~mm})$ の関係を Table 6 に示す。また, 以上のねじり剛性と最大荷重の関係 をFig. 15 に示す。これらより，断面が多角化するほど， $I_{\mathrm{c}}$ が わずかに大きくなることが確認された。ねじり剛性の差異は 角一つあたりでは小さいが, 断面全体ではその影響は大きい と考えられる。また， $I_{\mathrm{c}}$ の増加に伴い， $P_{\max }$ が大きくなる傾 向が確認された。これは, ねじり剛性の増加によって, 角管 断面が変形しにくくなったためだと思われる。このように, 断面にリブを有する多角管では，角部のねじり剛性が最大荷 重に影響を及ぼしていると考えられる。

\section{4. 結言}

本研究では，多角管の角数と内部に設ける補強リブが変形
挙動に及ぼす影響について検討した結果，以下の結論を得た。

（1）本軸長の範囲では，軸長が最大荷重に及ぼす影響は小さ w。

（2）断面形状が多角化しても, 生じる最大荷重に大きな差異 は見られず，平均荷重が大きくなる。

（3）補強リブは角部のねじり剛性を著しく増加させ，それに 伴い，最大荷重も大きくなる。

（4）断面のねじり剛性が大きくなるほど変形しにくくなり, 最大荷重の大きさが大きくなる。

（5）本研究の範囲では, 最大荷重が小さく, 平均荷重を向上 させることから, 衝撃吸収部材として適するのは断面に リブを持たない多角形の筒状体である。

\section{参 考 文 献}

1) J. M. Alexander: Q. J. Mech. Appl. Math., 13 (1960), 10-15.

2) W. Abramowicz and N. Jones: Int. J. Impact Eng., 2 (1984), 179-208.

3) 村瀬勝彦, ノーマン・ジョーンズ：材料, 42 (1993), 14201426.

4) Q. Meng, S. T. S. Al-Hassani and P. D. Soden: Int. J. Mech. Sci., 25 (1983), 747-773.

5) V. Tarigopula, M. Langseth, O. S. Hopperstad and A. H. Clausen: Int. J. Impact Eng., 32 (2006), 847-882.

6) H. Schneider and N. Jones: Int. J. Mech. Sci., 45 (2003), 2061-2081.

7) 萩原一郎, 津田政明, 佐藤佳裕: 日本機械学会論文集 A 編, 55 (1989), 1407-1415.

8) D. Karagiozova: Int. J. Impact Eng., 30 (2004), 143-166.

9) D.-K. Kim, S. Lee and M. Rhee: Mater. Des., 19 (1998), 179-185.

10) 伊藤清文, 熊谷正樹：塑性と加工, 56 (2015), 8-12.

11) J. Fleischer, G. Lanza, S. Dosch, J. Elser and W. Pangboonyanon: Procedia CIRP, 18 (2014), 221-225.

12) J. Fang, Y. Gao, G. Sun, N. Qiu and Q. Li: Thin-walled Struct., 95 (2015), 115-126.

13) X. Zhang, Z. Wen and H. Zhang: Thin-walled Struct., 84 (2014), 263-274.

14) M. Miyazaki and H. Negishi: Mater. Trans., 44 (2003), 1566-1570.

15) M. Miyazaki and M. Yamaguchi: Procedia Eng., 81 (2014), 10671072.

16) チモシェンコ：座屈理論, 仲 威雄, 譸川聲一, 久田俊彦 (訳), コロナ社, (1954), 221-225.

17) 宮崎 忠, 根岸秀明：軽金属, 52（2002）， 313-317.

18) 宮崎 忠, 横谷圭亮: 第66回塑性加工連合講演会講演論文 集, (2015)，395-396.

19）宮崎 忠, 横谷圭亮, 東條湧介: 平成 28 年度塑性加工春季講 演会講演論文集，（2016），169-170.

20) K. Yokoya, M. Miyazaki and Y. Tojo: Mater. Sci. Forum, 910 (2017), 117-122.

21) K. Yokoya, M. Miyazaki, Y. Tojo and M. Yamashita: Procedia Eng., 207 (2017), 251-256.

22) 山下 実, 後藤 學, 高橋隆博, 澤入安彦: 日本機械学会論文 集A編，68（2002），668-673.

23）山下 実, 後藤 學, 高橋隆博, 澤入安彦: 日本機械学会論文 集A編，68（2002），217-222.

24) M. Yamashita, H. Kenmotsu and T. Hattori: Thin-walled Struct., 69 (2013), 45-53.

25) M. Miyazaki, H. Endo and H. Negishi: J. Mater. Process. Technol., 85 (1999), 213-216.

26) M. Yamashita, H. Kenmotsu and T. Hattori: Thin-walled Struct., 50 (2012), 37-44.

27) S. Tanimura, H. Hayashi, T. Yamamoto and K. Mimura: J. Solid Mech. Mater., 3 (2009), 1263-1273.

28) J. Chung and G. M. Hulber: Comput. Methods Appl. Mech. Eng., 118 (1994), 1-11.

29) S. P. Timoshenko and J. N. Goodier: Theory of Elasticity 3rd ed., McGraw-Hill, New York, (1970), 291-353. 